\title{
Body Morphometry and Development of the Digestive System of Grey Partridge (Perdix Perdix) Depending on Age and Gender
}

\section{-Author(s)}

\section{Kokoszyński D' \\ Biegniewska M" \\ Wilkanowska Al \\ Saleh M"II \\ Bernacki Z' \\ Stęczny KIv \\ Kmiecik M}

\section{Professor, Department of Poultry Breeding, Faculty of Animal Breeding and Biology, UTP University of Science and Technology, Bydgoszcz, Poland \\ " Doctor of Philosophy, Department of Poultry Breeding, Faculty of Animal Breeding and Biology, UTP University of Science and Technology, Bydgoszcz, Poland \\ III Master of Science, Department of Poultry and Animal Production, Faculty of Agriculture, Sohag University, Sohag, Egypt \\ Iv Master of Science, Department of Poultry Breeding, Faculty of Animal Breeding and Biology, UTP University of Science and Technology, Bydgoszcz, Poland \\ $\checkmark$ Master of Science, Division of Animal Product Evaluation, Faculty of Animal Breeding and Biology, UTP University of Science and Technology, Bydgoszcz, Poland}

\section{Mail Address}

Corresponding author e-mail address Dariusz Kokoszyński

UTP University of Science and Technology Faculty of Animal Breeding and Biology

Department of Poultry Breeding

Mazowiecka 28, 85-084 Bydgoszcz, Poland Tel: $\quad$ +48523749706

Email: kokoszynski@utp.edu.pl

\section{-Keywords}

Body dimensions, gender, grey partridge growth, intestine.

\section{ABSTRACT}

The experiment used 100 grey partridges (Perdix perdix L.), which were reared first in confinement and later in aviaries. Partridges were lighter and had greater body dimensions at 36 weeks compared to 12 weeks except for trunk length. Older birds showed greater values ( $p>0.05$ ) of compactness and lower values of massiveness and longleggedness. Significant differences were found for keel length in females. At 36 weeks, male and female partridges had significantly greater total intestinal length, males had significantly longer small intestine and rectum, and females were characterized by significantly longer caeca and greater $(p<0.05)$ intestine to body length ratio. Older birds had significantly greater gizzard weight and percentage and heart percentage (males and females), as well as significantly lower liver weight (males) and spleen weight and percentage. The present study provided information on the growth and development of farmed grey partridges before release into the natural environment.

\section{INTRODUCTION}

Grey partridge (Perdix perdix L.), also known as the Hungarian Partridge or English Partridge, is a bird in the family Phasianidae. This middle-sized bird has a head-to-tall length of about $30 \mathrm{~cm}$, wingspan about $45 \mathrm{~cm}$ and body weight from $290 \mathrm{~g}$ to $475 \mathrm{~g}$ (Meriggi et al. 2007; Pis, 2012).

The growth traits of young partridges (up to 9 months of age) were investigated, among others, by Kobriger (1980), Liukkonen-Anttila et al. (1999), Pis (2012), Nowaczewski et al. (2014). Kobriger (1980) reported that until 17 weeks of age, grey partridges achieve the highest daily weight gains at 4 weeks $(9.6 \mathrm{~g} /$ day), and the lowest at 16 weeks of growth $(0.1 \mathrm{~g} /$ day). In a more recent study (Nowaczewski et al., 2014), the highest weight in grey partridge were recorded between 6 and 9 weeks of age.

The growth and development of muscle, adipose and bone tissue are most often measured by cutting the carcass (dissection). Breast muscle content of eviscerated carcasses from grey partridges ranges from $27.3 \%$ to $36.0 \%$ (Adamski \& Kuźniacka 2007; Večerek et al., $2008)$ and is higher than in 42-day-old broiler chickens (22.5-25.3\%). The proportion of leg muscles (20.7-20.8\%) in grey partridge carcasses is similar to that noted in broiler chickens (21.1\%) (Azizi et al., 2012; Biesiada-Drzazga et al., 2011).

The development of grey partridges is also reflected in the weight and dimensions of the internal organs. Putaala \& Hissa (1995) showed that compared to wild grey partridges, captive grey partridges were significantly heavier, had shorter small intestines and caeca, as well as lower weight and proportion of the heart, gizzard and liver. 
Kokoszyński D, Biegniewska M, Wilkanowska A, Saleh M, Bernacki Z, Stęczny K, Kmiecik M
Body Morphometry and Development of the Digestive System of Grey Partridge (Perdix Perdix) Depending on Age and Gender
Grey partridges begun to be bred on farms after the population of this valuable game bird species rapidly declined in Poland and other European countries in the 1970s and 1980s (Panek, 2000). Despite the measures undertaken, the grey partridge population has declined in Poland in recent years, which is very unfavorable. In 2005 there were 347,000 partridges in Poland and in 2015 this number declined to 284,000 (Concise Statistical Yearbook of Poland, 2016). The lack of studies on most of the traits evaluated in this experiment in grey partridges (Perdix perdix) farmed in Poland was the motivation behind the present study.

The aim of the study was to determine the effect of grey partridge age and gender on body weight and dimensions, body conformation indices, length and diameter of intestine and intestinal segments, as well as the weight and proportion in the body of the main internal organs.

\section{MATERIALS AND METHODS}

The experiment was carried out at the Department of Poultry Breeding of the UTP University of Science and Technology in Bydgoszcz with approval of the Ethics Committee No. 27/2012. The subjects were 100 grey partridges (Perdix perdix L.).

During the first weeks of life, partridges were kept in an environmentally controlled confinement facility, and later in an outdoor aviary. From 1 to 16 weeks of age, birds were fed ad libitum with complete commercial diets for meat partridges. Partridges received a diet containing $26.0 \% \mathrm{CP}$ and $12.1 \mathrm{MJ}$ metabolizable energy (ME) until 2 weeks, a diet containing $22.0 \%$ CP and 11.9 MJ ME between 3 and 4 weeks, and a diet containing 17\% CP and 11.9 MJ ME per kg between 5 and 16 weeks of age. From 17 to 36 weeks, the birds were kept in an aviary ( 2.5 $\mathrm{m}^{2}$ per bird) and fed with wheat grain, rapeseed grain, and coarsely ground maize grain.

At the end of 12 and 36 weeks, 10 males and 10 females (40 birds in total) with body weight similar for a given gender on each evaluation date, were selected for slaughter. Partridges were selected based on conformation and/or plumage traits. After slaughter, plucking and evisceration, the gender of the analyzed partridges was identified again based on the appearance of their reproductive organs. Birds were weighed individually on Precisa 5/12 electronic scales (Medicat) to the nearest $0.1 \mathrm{~g}$, after which they were subjected to body measurements (40 birds). Birds were tape-measured with an accuracy of $1 \mathrm{~mm}$ for length of trunk with neck - body length (between the first cervical vertebra and posterior superior tuberosity of the ischium), length of trunk (between tuberosity of shoulder joint and posterior edge of the ischium), chest circumference (behind wings through anterior edge of the keel and middle thoracic vertebra), length of keel (from the anterior to the posterior edge of the keel), length of lower thigh (along the shin bone) and length of shank (between tarsal joint and posterior area of the fourth toe at its base). Body weight and body measurement values were used to calculate the body conformation indices of massiveness (percentage ratio of body weight in $\mathrm{kg}$ to trunk length in $\mathrm{cm}$ ), compactness (percentage ratio of chest circumference to trunk length in $\mathrm{cm}$ ) and long-leggedness (percentage ratio of shank length to body length in $\mathrm{cm}$ ) (Kokoszyński et al., 2017).

After the measurements, birds were slaughtered, defeathered and eviscerated, and the digestive tract was separated. The length of small intestine, caeca and rectum was tape measured to the nearest $0.1 \mathrm{~cm}$, and the diameter of these intestinal segments (initial, middle and final parts) was measured with electronic calipers to the nearest $0.001 \mathrm{~mm}$.

In addition, after evisceration, the following parts were separated and weighed on a Medicat 160M scales to the nearest $0.001 \mathrm{~g}$ : gizzard (without gastric content), proventriculus (without gastric content), liver (without gallbladder), heart, and spleen. Thereafter, their percentage in preslaughter body weight was determined.

The numerical data were analyzed statistically by calculating arithmetic mean and standard deviation $($ mean \pm SD) for the analysed traits using SAS/STAT version 9.4. Significance of differences between the mean values of the age groups was determined using Tukey-test pair-wise comparison test. Differences were considered significant at $p<0.05$.

\section{RESULTS AND DISCUSSION}

At 12 weeks of age, male and female grey partridges had greater body weight compared to 36-week-old birds. With advancing age, the body dimensions increased except for the trunk length. On both evaluation dates, males were heavier and had greater body dimensions than females. Significant differences were only found for keel length in females (Table 1). In young grey partridges, Kobriger (1980) found higher body weight in 12-week-old birds (357 g), and Nowaczewski et al. (2014) lower body weight 
Table 1 - Body weight and body dimensions of grey partridges of different ages.

\begin{tabular}{|c|c|c|c|c|}
\hline \multirow{3}{*}{ Trait } & \multicolumn{4}{|c|}{ Age - gender } \\
\hline & \multicolumn{2}{|c|}{$12 w k$} & \multicolumn{2}{|c|}{$36 w k$} \\
\hline & females & males & females & males \\
\hline Body weight (g) & $324.20 \pm 16.99$ & $344.80 \pm 35.73$ & $285.60 \pm 57.95$ & $302.00 \pm 62.84$ \\
\hline Trunk with neck length $(\mathrm{cm})$ & $17.30 \pm 0.44$ & $17.60 \pm 0.54$ & $18.16 \pm 0.23$ & $18.40 \pm 0.82$ \\
\hline Trunk length $(\mathrm{cm})$ & $12.10 \pm 0.65$ & $12.30 \pm 0.67$ & $11.86 \pm 0.21$ & $12.20 \pm 0.76$ \\
\hline Chest circumference $(\mathrm{cm})$ & $17.60 \pm 0.65$ & $18.30 \pm 0.44$ & $18.00 \pm 0.72$ & $18.80 \pm 0.65$ \\
\hline Keel length $(\mathrm{cm})$ & $5.50 \pm 0.10^{a}$ & $6.10 \pm 0.41$ & $6.40 \pm 0.12^{b}$ & $6.50 \pm 0.54$ \\
\hline Lower thigh length $(\mathrm{cm})$ & $7.70 \pm 0.27$ & $7.80 \pm 0.57$ & $7.86 \pm 0.21$ & $8.10 \pm 0.54$ \\
\hline Shank length $(\mathrm{cm})$ & $5.30 \pm 0.27$ & $5.60 \pm 0.42$ & $5.40 \pm 0.22$ & $5.70 \pm 0.23$ \\
\hline
\end{tabular}

Each value represents the mean \pm standard deviation.

$a, b$ Means of traits in rows within sexes, marked with different letters differ significantly $(p<0.05)$.

in grey partridges (12-week-old, male $295 \mathrm{~g}$, female $282 \mathrm{~g}$ ) than in our study. Compared to birds aged 36 weeks, higher body weight of grey partridges (383 g) was reported at 9 months by Putaala \& Hissa (1995). The lower body weight of the birds analyzed at the age of 36 weeks was due to the introduction of restricted feeding (wheat grain, maize grain, rapeseed) from 17 weeks of age. This system of feeding is recommended when partridges are planned to be introduced to hunting grounds. Probably, increasing the aviary area to $2.5 \mathrm{~m}^{2}$ per bird also had an effect on body weight.
Liukkonen-Anttila et al. (1999) observed the body weight of grey partridges to decrease after 6 weeks of feeding sprouted (raw, dry) barley, oat grain and weed seeds (natural diet) compared to birds receiving a crumbled or pelleted commercial diet.

Age and gender had no significant effect ( $p>0.05$ ) on the indices of massiveness, compactness and longleggedness. Older birds showed higher compactness, and lower massiveness and long-leggedness values. Higher values of the indices were calculated for males than females on both evaluation dates (Table 2).

Table 2 - Body conformation indices of grey partridges of different ages.

\begin{tabular}{|c|c|c|c|c|}
\hline \multirow{3}{*}{ Trait } & \multicolumn{4}{|c|}{ Age - gender } \\
\hline & \multicolumn{2}{|c|}{$12 \mathrm{wk}$} & \multicolumn{2}{|c|}{$36 w k$} \\
\hline & females & males & females & males \\
\hline Massiveness index (\%) & $2.68 \pm 0.11$ & $2.80 \pm 0.42$ & $2.41 \pm 0.49$ & $2.48 \pm 0.42$ \\
\hline Compactness index (\%) & $145.45 \pm 7.56$ & $148.78 \pm 8.66$ & $151.77 \pm 10.59$ & $154.09 \pm 12.92$ \\
\hline Long-leggedness index (\%) & $30.64 \pm 1.43$ & $31.82 \pm 3.08$ & $29.73 \pm 0.34$ & $30.98 \pm 1.31$ \\
\hline
\end{tabular}

Each value represents the mean \pm standard deviation.

Analysis of the data in Table 3 shows that 36-weekold partridges had greater total length of intestine and its segments (small intestine, caeca, and rectum) compared to 12-week-old birds. The intestine to body length ratio was greater in older partridges. Statistically significant effects of age were found for total intestinal length in males and females, small intestine and rectum length in males, and caeca length and intestine to body length ratio in females. In a study by LiukkonenAnttila et al. (1999), grey partridges at the age of approximately 9 months had shorter small intestine $(40.8 \mathrm{~cm}$ or $42.6 \mathrm{~cm})$ and caeca $(19.1 \mathrm{~cm})$, whereas Putaala \& Hissa (1995) reported similar lengths of small intestine $(56.6$ or $62.1 \mathrm{~cm})$ and caeca $(26.2 \mathrm{~cm}$ or 30.0 $\mathrm{cm})$ compared to our investigation. Kasperska et al. (2012) found increased lengths of the oesophagus

Table 3 - Length of intestine and its segments, and the intestine to body length ratio in grey partridges of different ages.

\begin{tabular}{|c|c|c|c|c|}
\hline \multirow{3}{*}{ Trait } & \multicolumn{4}{|c|}{ Age - gender } \\
\hline & \multicolumn{2}{|c|}{$12 w k$} & \multicolumn{2}{|c|}{36 wk } \\
\hline & females & males & females & males \\
\hline Small intestine & $55.90 \pm 2.45$ & $57.50 \pm 3.20^{a}$ & $68.80 \pm 4.91$ & $62.60 \pm 4.82^{b}$ \\
\hline Caeca & $27.00 \pm 2.00^{a}$ & $28.90 \pm 1.67$ & $33.80 \pm 3.03^{b}$ & $31.50 \pm 5.12$ \\
\hline Rectum & $6.80 \pm 1.15$ & $6.20 \pm 0.76^{a}$ & $7.88 \pm 2.29$ & $8.50 \pm 1.15^{b}$ \\
\hline Total intestine & $89.70 \pm 3.58^{a}$ & $92.60 \pm 4.44^{a}$ & $110.38 \pm 6.85^{b}$ & $102.60 \pm 6.07^{b}$ \\
\hline Intestine : body length ratio & $5.18 \pm 0.17^{\mathrm{a}}$ & $5.26 \pm 0.32$ & $6.08 \pm 0.50^{b}$ & $5.58 \pm 0.34$ \\
\hline
\end{tabular}

Each value represents the mean \pm standard deviation.

$a, b$ Means of traits in rows within sexes, marked with different letters differ significantly $(p<0.05)$. 
and crop $(p<0.05)$ and rectum as partridges became older and shorter lengths of small intestine and caeca in 52-week-old birds compared to 13-week-old birds. Kokoszyński et al. (2010) noted greater lengths of the small intestine, caeca and rectum in males that received, from 5 to 16 weeks of age, whole wheat grain $(30 \%)$ and a pelleted diet (70\%) compared to birds fed commercial diets alone. However, an inverse pattern was noted in females.
With the advancing age of partridges, the diameter of small intestine and caeca increased in males and females, and the rectum diameter increased in females. Significant differences were found for caeca diameter in females. At the age of 12 weeks, males had greater diameters of caeca and rectum than females, and at 36 weeks males showed smaller diameters of small intestine, caeca, and rectum compared to females (Table 4).

Table 4 - Diameter of intestinal segments in grey partridges of different ages.

\begin{tabular}{|c|c|c|c|c|}
\hline \multirow{3}{*}{ Trait } & \multicolumn{4}{|c|}{ Age - gender } \\
\hline & \multicolumn{2}{|c|}{$12 w k$} & \multicolumn{2}{|c|}{$36 w k$} \\
\hline & females & males & females & males \\
\hline Small intestine (mm) & $3.92 \pm 0.54$ & $3.73 \pm 0.55$ & $4.13 \pm 0.37$ & $3.86 \pm 0.34$ \\
\hline Caeca $(\mathrm{mm})$ & $3.94 \pm 0.20^{a}$ & $4.07 \pm 0.78$ & $4.30 \pm 0.26^{b}$ & $4.10 \pm 0.80$ \\
\hline $\operatorname{Rectum}(\mathrm{cm})$ & $4.16 \pm 0.93$ & $4.37 \pm 0.93$ & $4.18 \pm 0.73$ & $3.63 \pm 0.79$ \\
\hline
\end{tabular}

Each value represents the mean \pm standard deviation.

$a, b$ Means of traits in rows within sexes, marked with different letters differ significantly $(p<0.05)$.

At 36 weeks of age, males and females had lighter proventriculus, liver and spleen, and heavier gizzard and heart compared to birds of the same gender aged 12 weeks. Significant differences were observed for the weight of gizzard, proventriculus and spleen in females, and for the weight of gizzard, liver and spleen in males (Table 5).
The proportion of internal organs in the body of partridges changed with age (Table 6). With advancing age, the percentage of gizzard and heart increased, while spleen percentage decreased significantly $(p<0.05)$ in males and females. Older birds were characterized by non-significantly lower proventriculus percentage (males and females), and lower liver

Table $\mathbf{5}$ - Weight of internal organs in grey partridges of different ages.

\begin{tabular}{|c|c|c|c|c|}
\hline \multirow{3}{*}{ Trait } & \multicolumn{4}{|c|}{ Age - gender } \\
\hline & \multicolumn{2}{|c|}{$12 \mathrm{wk}$} & \multicolumn{2}{|c|}{$36 \mathrm{wk}$} \\
\hline & females & males & females & males \\
\hline Gizzard (g) & $6.21 \pm 0.48^{a}$ & $6.47 \pm 0.81^{a}$ & $7.88 \pm 0.63^{b}$ & $7.68 \pm 1.12^{b}$ \\
\hline Proventriculus (g) & $1.00 \pm 0.10^{a}$ & $1.02 \pm 0.16$ & $0.83 \pm 0.07^{b}$ & $0.88 \pm 0.12$ \\
\hline Liver $(\mathrm{g})$ & $6.82 \pm .49$ & $6.93 \pm 0.42^{\mathrm{a}}$ & $6.00 \pm 1.63$ & $5.37 \pm 0.59^{b}$ \\
\hline Heart (g) & $2.07 \pm 0.28$ & $1.92 \pm 0.22$ & $2.10 \pm 0.44$ & $2.10 \pm 0.57$ \\
\hline Spleen (g) & $0.15 \pm 0.05^{a}$ & $0.25 \pm 0.08^{a}$ & $0.07 \pm 0.01^{b}$ & $0.11 \pm 0.04^{b}$ \\
\hline
\end{tabular}

Each value represents the mean \pm standard deviation.

a,bMeans of traits in rows within sexes, marked with different letters differ significantly $(p<0.05)$.

percentage (males). In another experiment, Millan et al. (2001), based on analysis of the results of earlier studies, confirmed that farm-reared red-legged partridges (Alectoris rufa) have significantly lower proportions of liver, spleen and pancreas compared to wild partridges. This suggests a significant effect of rearing system (including diet composition) on the development of visceral organs, which was confirmed in our study. Yamak et al. (2016) found significantly $(p<0.05)$ lower heart weight and higher liver weight in partridges (Alectoris chukar) kept in the free-range compared to the barn system between 14 and 18 weeks of age. Compared to females, males were characterized by significantly $(p<0.01)$ higher weight of the heart, liver, gizzard, and edible inner organs.

\section{CONCLUSIONS}

In conclusion, the age and gender of birds had no significant effect on body weight and dimensions except for keel length in females. Thirty-six-week-old partridges (fed wheat grain, maize grain and rapeseed from 17 weeks of age) had significantly longer intestine, intestinal segments and the intestine to body length ratio compared to younger birds. Gizzard weight increased significantly with the age of females, and the 
Table 6 - Proportion of internal organs (\%) in the body weight of grey partridges of different ages.

\begin{tabular}{lcccc}
\hline \multirow{2}{*}{ Trait } & \multicolumn{3}{c}{ Age - gender } \\
\cline { 2 - 5 } & \multicolumn{3}{c}{12 wk } & \multicolumn{3}{c}{36 wk } \\
\cline { 2 - 5 } & females & males & females & males \\
\hline Gizzard (\%) & $1.92 \pm 0.12^{\mathrm{a}}$ & $1.88 \pm 0.11^{\mathrm{a}}$ & $2.76 \pm 0.60^{\mathrm{b}}$ & $2.54 \pm 0.97^{\mathrm{b}}$ \\
Proventriculus (\%) & $0.30 \pm 0.03$ & $0.30 \pm 0.06$ & $0.29 \pm 0.04$ & $0.29 \pm 0.13$ \\
Liver (\%) & $2.10 \pm 0.33$ & $2.01 \pm 0.52$ & $2.10 \pm 0.35$ & $1.78 \pm 0.49$ \\
Heart (\%) & $0.64 \pm 0.05^{\mathrm{a}}$ & $0.56 \pm 0.12^{\mathrm{a}}$ & $0.74 \pm 0.03^{\mathrm{b}}$ & $0.70 \pm 0.04^{\mathrm{b}}$ \\
Spleen (\%) & $0.04 \pm 0.01^{\mathrm{a}}$ & $0.07 \pm 0.02^{\mathrm{a}}$ & $0.02 \pm 0.01^{\mathrm{b}}$ & $0.04 \pm 0.01^{\mathrm{b}}$ \\
\hline
\end{tabular}

Each value represents the mean \pm standard deviation.

$a, b$ Means of traits in rows within sexes, marked with different letters differ significantly $(p<0.05)$.

weight of their proventriculus and spleen decreased significantly. Older females had significantly heavier gizzard and lighter liver and spleen. In male and female partridges aged 36 weeks, the proportion of gizzard and heart was significantly higher, while females and males had a significantly lower spleen percentage.

\section{REFERENCES}

Adamski M, Kuźniacka J. Effect of sex, slaughter value and tissue composition in 12-week-old grey partridge. Animal Science 2007;1:910.

Azizi B, Sedeghi G, Karimi A, Abed F. Effects of dietary energy and protein dilution and time of feed replacement from starter to grower on broiler chickens performance. Journal of Central European Agriculture 2011;12:44-52.

Biesiada-Drzazga B, Janocha A, Bombik T, Rojek A, Brodzik U. Evaluation of the growth and slaughter value of the Ross 308 broiler chickens. Acta Scientiarum Polonorum, Zootechnica 2011;10(3):11-20.

Concise Statistical Yearbook of Poland. Some game animal. Warszawa: Ed. Central Statistical Office; 2016.

Cramp S, Simmons KEL. Perdix perdix partridge. In: Svensson L, Madge S. Handbook of the birds of Europe. The Middle East and North Africa. The birds of the West Palearctic. New York: Oxford University Press; 1980. v.2, p.486-496.

Kasperska D, Kokoszyński D, Korytkowska H, Mistrzak M. Effect of age and sex on digestive tract morphometry of guinea fowl (Numida meleagris L.) Folia Biologica (Kraków) 2012;60:45-49.

Kobriger GD. Foods, food availability, nutrition, and body weights of grey partridge in North Dakota. Proceedings of the 2th Perdix. Gray Partridge Workshop; 1980; Moscow. Idaho. p.70-86.
Kokoszyński D, Bernacki Z, Cisowska A. The effect of using whole grain in the diet of game pheasants on their body weight, dimensions and development of some internal organs. Folia Biologica (Kraków) 2010;58:101-106

Kokoszyński D, Bernacki Z, Saleh M, Stęczny K, Binkowska M. Body conformation and internal organs characteristics of different commercial broiler lines. Brazilian Journal of Poultry Science 2017;19(1):47-52.

Liukkonen-Anttila T, Putaala A, Hissa R. Does shifting from a commercial to a natural diet affect the nutritional status of hand-reared grey partridges Perdix perdix? Wildlife Bioliogy 1999;5:147-156.

Millan J, Gortázar C, Villafuerte R. Marked differences in the splanchometry of farm-bred and wild red-legged partridges (Alectoris rufa L). Poultry Science 2001;80:972-975.

Nowaczewski S, Kolonos S, Krystianiak S, Kontecka H, Górecki M. Body weight and some biometrical traits of grey partridges (Perdix perdix) at different ages. Bulgarian Journal of Agriculture Sciences 2014;20:962966.

Panek M. Situation of grey partridges in Poland in the years 19982000. Proceeding of the 2th Conference Small Game as Part of the Biodiversity of the Natural Environment; 2000; Włocławek. Poland. p.145-154.

Pis T. Growth and development of chicks of two species of partridges:the grey partridge (Perdix perdix) and the chukar (Alectoris chuckar). British Poultry Science 2012;53:141-144.

Putaala A, Hissa R. Effects of hand-rearing on physiology and anatomy in the grey partridge. Wildlife Biology 1995;1:27-31.

Večerek V, Serman V, Vitula F, Strakova E, Suchý P, Mas N, et al. Slaughter value of selected breeds of wildfowl. Krmiva 2008;50:335-344.

Yamak US, Sarica M, Boz MA, Ucar A. The effect of production system (barn and free-range), slaughtering age and gender on carcass traits and meat quality of partridges (Alectoris chucker). British Poultry Science 2016;57:185-192. 
